\title{
Does BLE technology contribute towards improving marketing strategies, customers' satisfaction and loyalty? The role of open innovation
}

\author{
Haitham Alzoubi $^{\mathrm{a}}$, Muhammad Alshurideh ${ }^{b^{*}}$, Barween Al Kurdic ${ }^{\mathrm{c}}$, Iman Akour ${ }^{\mathrm{d}}$ and Ramsha \\ Aziz $^{\mathrm{e}}$
}

${ }^{a}$ School of Business, Skyline University College, Sharjah, United Arab Emirates

${ }^{b}$ Department of Marketing, School of Business, The University of Jordan. Amman, Jordan

${ }^{c}$ Department of Marketing, Faculty of Economics and Administrative Sciences, The Hashemite University, Zarqa, Jordan

${ }^{d}$ Department of Information Systems, College of Computing and Informatics, University of Sharjah, United Arab Emirates

${ }^{e}$ United Arab Emirates University, United Arab Emirates

\section{CH R O N I C L E}

Article history:

Received: July 22, 2021

Received in revised format: Sep-

tember 16, 2021

Accepted: December 14, 2021

Available online: December 14,

2021

Keywords:

BLE (Beacon) Technology

Proximity marketing

Customers' satisfaction

Customers' loyalty

\section{A B S T R A C T}

\begin{abstract}
The purpose of this study is to explore the marketing strategies for the introduction of Beacons technology applications (BLE) technology in businesses and how it can convert potential clients into satisfactory and loyal customers. Open innovation is the pathway to taking businesses to the next level with the help of and introduction to BLE technology contributions. Companies are flexible towards adopting new technologies to make sure that their marketing strategies are working positively. Global Village Dubai was the market that we targeted to study the customers' needs and wants. This was done through 138 questionnaires distributed among 159 stores that met our research criteria. We used ANOVA through the SPSS program for analysis of the data. The results supported all our hypothesis of the study, which means there is a positive and strong relationship of adopting BLE technology on customers' satisfaction which leads towards customers' loyalty, making them stick to the brand for long term. The results of our research revealed that Beacons technology applications have positively influenced marketing strategies which in turn have impacted customer satisfaction and loyalty. The proximity marketing is the best strategy developed in lieu of open innovation. Future studies are welcomed for analyzing the same model in perspective of other markets for clearer advocacy of the hypothesis that proximity marketing is the marketing strategy that helps in customers' happiness leading towards their loyalty.
\end{abstract}

\section{Introduction}

The aim of this research is shedding light on the open innovations' applications and their use in business operations (Alameeri, Alshurideh, \& Al Kurdi 2021; Nuseir, Aljumah, \& Alshurideh 2021; Obeidat et al. 2021). Specifically, to expand the understanding of how Beacons technology may affect consumer satisfaction and loyalty (Alzoubi, Alshurideh, and Ghazal 2021). This research discusses in detail how on one hand, applications of Beacons technology would serve proximity marketing operations. On the other hand, its relationship and impact on consumer satisfaction and loyalty. To properly comprehend all of the complicated aspects, this technology is investigated further by first understanding the distinction between beacon technology and conventional Bluetooth technology. Second, attempting to comprehend how it functions and which devices it may be utilized with. This article discusses in detail how this incredible technology may be connected with other apps and how it provides services. The study clearly demonstrates the advantages of employing technology and how it is used in the real world

* Corresponding author.

E-mail address: m.alshurideh@ju.edu.jo (M. Alshurideh)

(C) 2022 by the authors; licensee Growing Science, Canada. doi: $10.5267 /$ j.ijdns.2021.12.009 
to meet human needs, such as resolving the issue of consumer satisfaction by reacting to their requests and desires (Al Kurdi, Alshurideh, Salloum, et al. 2020; Al Kurdi, Alshurideh, and Salloum 2020; Turki et al. 2021). The way Bluetooth technology has positively influenced marketing techniques has been changed by open innovation, which has provided easy-to-use, adaptable, and successful marketing tactics.

Globalization has driven the globe to emerge as a global economy due to the massive changes in technology and social aspects of life brought about by globalization. Cultures, societies, information, technology, jobs, and business are all part of globalization (Abuhashesh, Alshurideh, \& Sumadi, 2021; Ahmad, Alshurideh, Al Kurdi, \& Salloum, 2021; Madi Odeh, Obeidat, Jaradat, Masa'deh, \& Alshurideh, 2021). Globalization has benefited cooperation in many ways by increasing nation-to-nation interdependence and expanding geographical footprints. Still, it has also pushed organizations into a ferocious and aggressive hunt for market share. As a result, the cooperation's subsequent efforts are focused on "consumer preference-based marketing methods" (Shirkhodaie \& Rastgoo-deylami, 2016). To satisfy customers and so gain brand loyalty, a more empirical approach is adopted (Abu Zayyad et al., 2021; Aljumah, Nuseir, \& Alshurideh, 2021; Hamadneh \& Al Kurdi, 2021). Cooperation has changed and refashioned itself due to globalization, and to gain a larger piece of the market, they now rely more heavily on innovation (Fernandes, 2021). According to the Organization for Economic Co-operation and Development (OCED) recommendations, a business innovation can be regarded in four ways: organizational innovation, product innovation, and service innovation. Process and marketing innovation are two types of innovation. Apart from the aforementioned, division of innovation can be in two broad categories based on its nature: closed innovation and open innovation (Fernandes, 2021). While closed innovation occurs within the confines of a company, open innovation refers to a model or framework that suggests businesses can leverage internal and external ideas to reach markets. Furthermore, open innovation has unlocked a wide range of previously unavailable resources through closed innovation at many levels of businesses (H Alzoubi, 2018).

Beacons are small, low-cost wireless transmitters that employ Bluetooth low energy technology to relay signals to other intelligent devices nearby. Beacon devices utilize a new technology called Bluetooth low energy or Bluetooth smart. For two key reasons, the innovative Bluetooth technology utilized in a Beacon differs from standard Bluetooth. It consumes extremely little energy for starters, and, secondly, it does not necessitate any pairings or connections (Bhattacharya, Canul, \& Knight, 2016). Beacon provides signals to smart devices to help users find their way around by making location-based searches and interactions accurate and straightforward. Beacons, unlike satellites, do not broadcast their location to many satellites; instead, they only communicate their location to the device receiving their identity or that Unique ID code. GPS can locate you anywhere on the planet, but it does not operate well indoors. To provide you with a location, GPS requires at least three satellites, and it frequently does so with an accuracy of 1-50 meters. On the other hand, Beacons can work both indoors and outdoors, and they can achieve greater precision (Bhattacharya et al., 2016).

Beacon devices use GPS technology to track a person's whereabouts when he or she is near a deployed Beacon. It can be used in various industries and promotes a new use case (Goodrich, 2013). Employing this technology in various industries where people engage with technology, such as transportation, news, hospitals, and tourism. Beacons send the news to users via a technique known as Geo-Fencing. Users receive location-specific news, and the news is presented until the user enters the perimeter of the site (Chen, Shin, Jiang, \& Kim, 2017). Apps can connect to beacons to obtain news that is relevant to their users based on their location. When a user walks by a location, a beacon sends a signal to the phone, and the app knows to offer an update of news relevant to that location for the duration of their visit. After they leave the area and the beacon signal is no longer detected, the app no longer displays that news. This is known as geofencing, and They may do it with both beacons and GPS. This type of Beacon is particularly useful for consumers who want to stay informed about current events. Still, it can also be used by organizations and apps that use emergency alerts. RapidSOS, for example, uses Bluetooth beacons to ensure that your location can be precisely recognized in an emergency (Chen et al., 2017).

Similarly, the tourism sector utilizes beacons to advertise neighboring hotels, restaurants, motels, and guest homes and lodges (Alaali et al., 2021). However, the employment of beacons in retail outlets is at the heart of the heat map. The Beacon devices send short, small messages to the person nearby, which directs the intelligent device to pull down material based on the location. It is used to direct visitors to facilities in malls, airports, museums, public buildings, or any other public space and to direct them to their favorite product or service (Bulusu, Heidemann, \& Estrin, 2001). Because GPS is only accurate to a certain degree, those with visual impairments can benefit from even more precise micro-navigation supplemented with beacons. Beacons aren't just for apps; Beacons may also use them with other technologies. Beacons are used by MTA trains in the New York City subway to communicate a broadcast signal between the train and the station's platform, informing commuters when their train will arrive (Bulusu et al., 2001; Gómez-de-Gabriel, Fernández-Madrigal, López-Arquillos, \& RubioRomero, 2019).

To revolutionize 'proximity marketing,' highly sophisticated Beacon modules are deployed. As a result, it is precise for object positioning and essential for delivering successful location-based services. Customer satisfaction and loyalty to the product or service would improve as a result. Baseball stadiums use beacons to direct fans to their seats or to fetch a hotdog. Beacons are used at American Eagle stores to inform shoppers about current promotions, rewards depending on their location, and other product recommendation (Alzoubi, 2018). Beacon marketing is a marketing tactic used by businesses to access as much customer data as possible. This is accomplished by gathering information based on a user's searches and clicks on multiple social media sites or simply the internet. The user's behaviors and preferences are then examined, and each user and each click 
are individualized. Within the Beacon servers, a separate database is maintained, and this data is then linked to the Beacon module. The Beacon module will track and notify any user within the module's radius depending on the tailored and unique information database. Proximity marketing refers to the entire ecosystem formed by numerous components such as hardware and software (Okamoto, Sasaki, \& Suzuki, 2017). Beacon technology is primarily utilized in proximity marketing to get people to interact with their preferred items and services. This is commonly utilized in retail businesses to increase consumer satisfaction across a wide range of products. Customer satisfaction is defined as the degree to which a product or service meets a customer's expectations. Furthermore, consumer happiness is influenced by service quality, price fairness, and perceived value. Customer satisfaction also leads to customer loyalty, which is defined as a collection of customer attitudes and behaviors that reflect their commitment to a brand, product, or service through positive word of mouth and the intention to purchase from a specific store again. The introduction of innovation and technology has improved the world, focusing on achieving or increasing consumer happiness and loyalty, which can be generated by quickly addressing their requests and wants (Okamoto et al., 2017).

This study proposes using beacons (low-cost Bluetooth, low-energy) in conjunction with an Intelligent Information System to improve retail operations. Furthermore, we propose implementation at Dubai's Global Village (public festival park) in the United Arab Emirates in this study. Because of the vast number of potential clients gathered around the stores in the Global Village, it is one of the excellent areas to use this new technology. As a result, the purpose of this paper is to see how Beacon may help retailers increase and attract potential customers who visit their stores daily, as well as to see how this approach affects customer satisfaction and loyalty. If you have never seen a beacon before, they are pretty simple gadgets comprising only three components: batteries, a central processing unit (CPU), and a radio. All beacons are BLE or Bluetooth low energy (you may also see it referred to as "BTLE"). This is critical since lower energy consumption enables beacons to operate for extended periods, frequently years, without the need to change the battery. If you hear the term BLE about Bluetooth beacons, keep in mind that all Bluetooth-enabled beacons are technically low-energy beacons (Bhosale, Benny, Jaison, Khot, \& Pati, 2019).

\section{Literature Review and Theoretical Background}

\subsection{Proximity Marketing and BLE (Beacon) Technology}

\subsubsection{Beacons Technology}

Beacon technology is a type of technology that consists of a small Bluetooth low-energy radio device that transmits signals and uses GPS technology (to communicate with other intelligent devices such as smartphones) to track a person's location and direct them to make their location-based searching more accurate and faster. Beacons Technology has been around for a while and has been steadily improving since its inception. Beacon is being used by businesses to lure customers to their store. BLE beacons (Bluetooth low energy) send signals to nearby smart devices (such as cell phones, watches, tablets, and so on) to initiate the conversation with nearby clients. For each pair conversation, each beacon device utilizes a different code. This beacon device is also dependable, as less energy allows beacon devices to be active for more extended periods of time without the need to replace the battery. As a result, Beacon began to be employed in the commercial world. Retailers are also interested in the various applications of beacons and how to make the most significant use of them. Customers can use this device to guide them to specific regions or items and uncover the most fantastic offers and deals. The following are domains or aspects in which Beacon Technology can be employed in the retail industry that will focus on our research (Girolami, Mavilia, \& Delmastro, 2020).

\subsubsection{Proximity-based Marketing}

All marketing efforts to target potential clients located nearby or within a specific location are referred to as proximity marketing. Designing a location-based marketing message that involves targeting potential customers with customized adverts and offers that fit those customers and providing them with helpful information and offers that result in win-win situations, encouraging them to make a purchase decision shortly (Shirkhodaie \& Rastgoo-deylami, 2016). Proximity marketing provides customers with information that may lead them to a specific location or product. It also assists businesses in increasing sales by directing actual offers to a specific consumer segment that is most likely to make a purchase (Al-Khayyal, Alshurideh, Al Kurdi, \& Salloum, 2020; Alkitbi, Alshurideh, Al Kurdi, \& Salloum, 2021; Mashaqi, Al-Hajri, Alshurideh, \& Al Kurdi, 2020). New techniques and technologies, including GPS, RFID, and Bluetooth, have lately been employed to improve proximity marketing approaches. They have been utilized to increase visibility and connectedness, as well as boost consumer happiness and loyalty (Alameeri, Alshurideh, Al Kurdi, \& Salloum, 2021; AlShehhi, Alshurideh, Al Kurdi, \& Salloum, 2020; Levesque, Durif, Boeck, \& Bilolo, 2015). Beacons are the most effective form of advertising. Once the user device enters the Beacon range, it can serve advertising messages directly to the user. These customized communications boost both the upsell and the consumer experience and increase customer satisfaction. One of the primary advantages of internet retailers over brick-andmortar retailers is that they have abundant methods for collecting client information. Beacons enable brick-and-mortar businesses to collect client information as well as information about their shopping behavior (Levesque \& Boeck, 2017). 
Loyalty Programs are a structured marketing method and strategy that Beacon should establish based on customer behavior information to encourage current customers to continue and repeat purchasing from the business and suggest the business's products/services. Customer loyalty programs are one of the most effective tactics for increasing sales and generating customer loyalty to continue to buy from the company (Alshurideh, 2019; Joghee et al., 2021; Santouridis \& Trivellas, 2010).

\subsubsection{Navigation system for in-store purchases}

In-store navigation system: This system uses GPS, Wi-Fi, or Bluetooth to guide customers inside the store using their smart devices to look for a specific location or item. Establishments create apps to help customers explore their stores. Developing an in-store navigation strategy will assist the store in providing a better shopping experience for customers, considering how customers can find what they need in the store more easily and quickly (Kusaladharma \& Tellambura, 2013).

\subsubsection{Marketing in real-time}

Real-time marketing refers to selling a product or service in real-time, such as right now or for current activity, by selecting a suitable approach to a specific customer at a particular location and time. Real-time marketing is a type of internal market research that aims to find the most appropriate offer for a given customer sales opportunity instead of traditional external marketing, which aims to find the most appropriate customers for a pre-defined offer. There are two forms of real-time marketing: event-driven focused on the audience and collaboration, and customer-driven, which is focused on the individual, data-driven, and customer-centric (Levesque \& Boeck, 2017). Beacons have a significant impact because they enable realtime communication. It enables customers to save valuable time in a variety of ways. Because targeted, timely messages alter the way customers enter the store, they diminish the likelihood of making a purchase. They act as a guide, assisting you in quickly locating the best product at the best price. Apart from push notifications, beacons enable two-way communication, in-store navigation, and channel analysis. Additionally, it enables retailers to identify, reward, and understand their most valuable customers. It also assists in increasing their loyalty and developing a stronger relationship with them (Al Dmour, Alshurideh, \& Shishan, 2014; Alshraideh, Al-Lozi, \& Alshurideh, 2017; Alshurideh, Masa'deh, \& Alkurdi, 2012). Keeping track of employee efficiency is another of its applications (Levesque et al., 2015 \& Hamadneh et al., 2021). Based on the above, we come to develop the following hypothesis:

\section{H1: Marketing Proximity has a positive impact on Adoption intention of BLE Technology.}

\subsection{Customer Satisfaction}

The degree to which a customer's expectations for a product or service were exceeded or satisfied is referred to as customer satisfaction. It is also thought to be a method of determining customer attitudes. Customers' satisfaction is defined as their perception or experience (satisfy/dissatisfy) as a result of comparing what they want with what they have already received. In some sense, customer contentment entails the consumer's inability to express dissatisfaction with the goods or service. However, if the product/service fails to match the customer's expectations, the consumer will be unhappy (Johnson, Karlay, Fregidou-Malama, Hyder, \& Johnson, 2018). The following dimensions explored for Customer satisfaction:

\subsubsection{Quality}

The examination of how well a product or service performs is referred to as product/service quality. Businesses, in general, need to measure the Quality of service they provide to their consumers to improve their business performance by quickly identifying and correcting any flaws or problems before they become visible to customers, resulting in higher customer satisfaction. Quality is the lifeblood of service delivery businesses, ensuring enhanced client satisfaction, a competitive edge, and long-term profits. While services and unbreakable relationships encompass both customers and service providers, these services might be intangible products or other valuable instruments that help clients solve difficulties. The difference between a customer's impression and expectation of service is referred to as service quality. It also refers to a service provider's capacity to match perceived service to expected service in order to achieve client satisfaction. As a result of rising global competition, businesses have chosen to expand their market size and improve service quality by raising customer expectations through technological advancements and globalization. Customer happiness is influenced by the Quality of service provided (Ryding, 2010; Siddiqi, 2011).

\subsubsection{Cost}

Price fairness is defined as a determination of the total price fairness of a product or service after considering both monetary and non-monetary expenses of acquisition. Price has long been one of the most important factors influencing both business and consumer behavior. Firms want to maximize their profits primarily through product/service pricing, whereas consumers seek out the best-priced products/services that will provide them with the most benefit. As a result, businesses must be able 
to predict how customers will react to specific pricing changes. The gap between a vendor's pricing and the price of a relative other party is characterized as acceptable, reasonable, or justifiable by a consumer's valuation and accompanying emotions. Customers' behavioral intentions might be influenced by price fairness (Ryding, 2010; Siddiqi, 2011).

\subsubsection{Perceived worth:}

Perceived value is defined as a customer's assessment of a product or service's benefits as well as its capacity to meet the customer's wants and expectations. Perceived worth When making a purchase, a buyer places higher importance on a product's benefit than its function. The relationship between perceived costs and perceived advantages can be used to estimate a customer's perceived value. The customer's values are influenced by several factors, including financial resources, product/service knowledge, and the shop's or service center's location. The development of customer value generation strategies is critical for attracting new customers, maintaining good customer relationships, and building customer loyalty (Ryding, 2010; Siddiqi, 2011).

\subsection{Customer Loyalty}

Customer loyalty refers to a customer's willingness to stay with them and their loyal behavior. Consumer happiness leads to customer loyalty (nice reply). Customer pleasure leads to customer loyalty, which is defined as a solid attachment to a specific brand, product, or service. Client pleasure is important, but customer loyalty is more profitable and more challenging to keep and build than it was in the past. Customers that are loyal to you will encourage others to buy from you without hesitation. Customer loyalty is earned through design decisions, and it necessitates customer-centered ways for determining what customers want and are interested in (Siddiqi, 2011). The dimensions of customer loyalty are as follows:

\subsubsection{The power of positive word of mouth}

Positive word of mouth: providing information to customers that highlight the benefits and qualities of a product/service and encourages them to use the product or service. It is discussing goods/services amongst people as opposed to advertisements for products/services by businesses. These discussions can be group discussions or individual advice and suggestions. People trust what they hear directly from other people more than what they hear from commercials. Therefore, word of mouth is one of the most potent ways to influence people and persuade them to buy a product/service (Santouridis \& Trivellas, 2010).

\subsubsection{Intention to purchase again}

Intention to repeat buying: This type of buying behavior demonstrates customers' willingness to buy a product from a specific store regularly. By focusing on online retailers, the intention to repeat purchases or client loyalty is critical for the success and longevity of any shop (Al Kurdi, Elrehail, Alzoubi, Alshurideh, \& Al-adaileh, 2021). Intention to repeat purchases has now become a critical criterion for dealers; repeat purchases save money and increase sales (Konečnik Ruzzier, Ruzzier, \& Hisrich, 2014).

\subsection{BLE (Beacon) technology and Customer Satisfaction}

According to Dudhane \& Pitambare (2015) article, employing beacons to provide location-based services to customers makes business operations more innovative. It gives an enormous value to customers, which improves customer happiness. Shops can use beacons to improve consumer experiences, improve business strategies, and increase income. Retailers and telecommunications carriers can collaborate to improve customer experience by personalizing offers and recommendations, empowering sales associates, and improving the consumer's in-store buying experience (Nemati, Khan, \& Iftikhar, 2010). Customers can be engaged in the right place at the right time by using beacons, which provide utility and value. The authors of this study argue that Bluetooth beacons can be highly beneficial to retailers in terms of customer analytics, operational analytics, revenue improvement, and partnering with service providers to improve customer experience (Ali et al., 2021). Mendelson discusses how a beacon can be set up with sensors to trigger a specific application. It recognizes users and begins offering locationbased services (LBS) like navigation, mapping, and information transmission and enabling emergency services (Ghazal et al., 2021). As a result, the total service quality for their in-store consumers has improved (Levesque et al., 2015). We can draw the following conclusion and establish the following hypothesis based on the above discussion:

$\mathbf{H}_{\mathbf{2}} \mathbf{a}$ : Adoption Intention of BLE Technology has a positive impact on customer satisfaction.

\subsection{Customer Loyalty and BLE (Beacon) Technology}

Mobile phones, according to Moody, have essentially taken over the planet. Every action a person does is now recorded on their smartphones. This paper discusses the firms' use of innovation (Beacon) to propel their brands ahead. According to the study, if companies focus on consumer benefits through digitalization, they can create positive branding outcomes and enhance customer loyalty. Entrepreneurs and advertisers try to develop seamless experiences despite the ever-changing landscape of digital and mobile technology to remain at the forefront of breakthroughs that propel manufacturers forward. This investigation looks into the innovative possibilities offered by location-based advertising technologies. The writer investigated how entrepreneurs may make the most of beacon-based conversation methods through a quantitative research survey and a 
review of literature on existing uses and concerns (Nicholas \& Shapiro, 2021). Overall, this research found that if manufacturers are mindful of customer skepticism and keep consumer benefits in mind, strategic and creative location-based implementation has a high probability of increasing corporate relevance in the digital age. (Dudhane \& Pitambare, 2015) also discuss how beacon technology applications might improve customer loyalty. Many organizations and developers see the potential of Bluetooth Beacon technology applications (Alzoubi \& Aziz, 2021). They are already utilizing it to provide relevant and contextual interactions to their customers while increasing customer loyalty (Alhamad et al., 2021). We can draw the following conclusion and establish the following hypothesis based on the above discussion:

$\mathbf{H}_{\mathbf{2}}$ : Adoption Intention of BLE Technology has a positive impact on customer loyalty.

\subsection{Impact of Customer Satisfaction on Customer Loyalty}

In their 2010 research, authors (Santouridis \& Trivellas, 2010) say that customer satisfaction dimensions have a considerable beneficial impact on customer loyalty. Customer service, price structure, and billing system are the service quality characteristics that have the most significant positive impact on customer satisfaction, which has a significant positive impact on customer loyalty (H. M. Alzoubi, Vij, Vij, \& Hanaysha, 2021). Patron joy has also been confirmed as a mediator in the carrier fine and purchaser loyalty relationship (Moody, 2015). Author Siddiqi discusses the relationship between service quality, customer happiness, and customer loyalty. In the banking industry, a survey with a sample size of 100 people was conducted (Alnuaimi, Alzoubi, Ajelat, \& Alzoubi, 2021). The results demonstrate that service quality has a positive relationship with customer satisfaction, and customer happiness has a positive relationship with customer loyalty. In this article, Mohammad Muzahid Akbar and Noorjahan Parvez (Akbar \& Parvez, 2009) discuss the relationship between customer pleasure and loyalty in the telecom business. Statistics compiled from 304 clients of a significant non-profit telecommunications company in Bangladesh (Joghee, Alzoubi, \& Dubey, 2020). The study's findings show that client pleasure and confidence are strongly and positively linked to client loyalty. Customer happiness is an essential mediator between client loyalty and perceived service quality (Alzoubi \& Yanamandra, 2020). The telecom service provider(s) may be motivated to figure out the best course of action to win consumers' trust by giving higher services to build a loyal client base if they have a clear understanding of the posited links among the examined factors (Siddiqi, 2011). We can draw the following conclusion and form the following hypothesis based on the above discussion:

\section{$\mathbf{H}_{3}$ : Customer Satisfaction has a positive impact on customer loyalty.}

\subsection{BLE (Beacon) Technology, Customer Satisfaction and Loyalty}

Customers' relationships with their favorite retailers are strengthened by beacons, which can give location-based services like personalized messaging, coupons, and promotions. As a result, it's a good strategy to meet customers' desire for more tailored marketing offers, which leads to client loyalty (Mehmood, Alzoubi, Alshurideh, Al-Gasaymeh, \& Ahmed, 2019). Beacons within a specific range emit Bluetooth signals. Each Beacon sends out a unique signal that may be read by a related app on a customer's phone, for example. Other technologies do not work in interior settings like retail malls or train stations, so this technology is better suited to them (Alzoubi, Ahmed, Al-Gasaymeh, \& Al Kurdi, 2020; Moody, 2015; Ng, She, \& Ran, 2020). We can draw the following conclusion and form the following hypothesis based on the above discussion:

\section{H4: Adoption Intention of BLE technology has a positive impact on Customer Satisfaction and Loyalty.}

\subsection{Retail Sector}

Retailing is an important commercial activity that allows customers to purchase goods and services from various merchants (Retail). Retailers can purchase products from a wholesaler or distributor, who acts as a middleman. The wholesaler brings together products from all across the world. It repackages them to make marketing and distribution more convenient. Retail differs from other industries in one fundamental way: it does not manufacture goods. Instead, retailers buy things in bulk from manufacturers. These products are subsequently marked up and sold to consumers (Haitham Alzoubi \& Ahmed, 2019) (Gajanova, 2019). The focus of this study was on Global Village in Dubai as a retail industry.

\subsubsection{Festival of the Global Village:}

It brings together the cultures of 90 countries from around the world in one location. It bills itself as the most prominent tourism, leisure, shopping, and entertainment project in the world. It is the first cultural, entertainment, family, and retail destination in the region. It attracts more than 5 million visitors each year and covers an area of 17,200,000 square feet). It has over 3000 different shops and attracts thousands of people each day.

\section{Conceptual Framework}

Beacon Technology is a relatively new technology that has not received much attention. This technology still has many potentials, and it's getting a lot of attention from researchers. Beacon technology applications can have a considerable positive impact in various industries, particularly in organizations and businesses all over the world. Our research on beacon technology applications, especially one of the most important ones, Customer Satisfaction, and Loyalty (Alnazer, Alnuaimi, \& Alzoubi, 2017; Gajanova, 2019), and, in particular, on Global Village. 


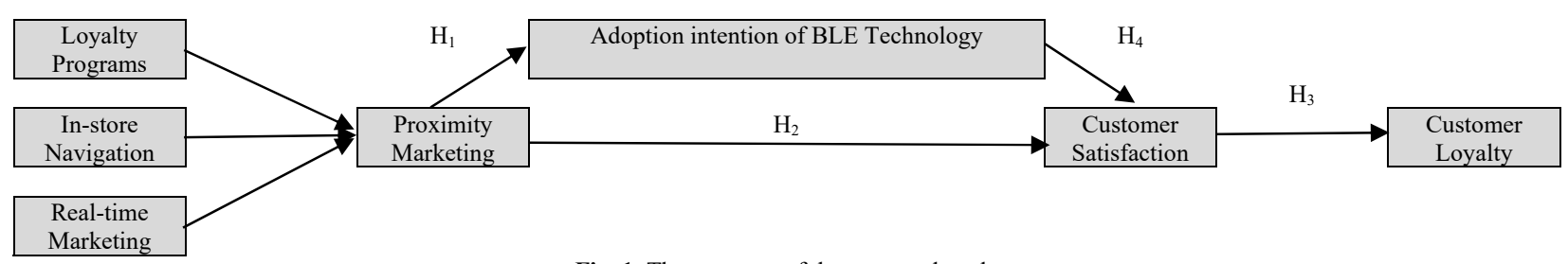

Fig. 1. The structure of the proposed study

\subsection{Study Methodology and Design}

This research aims to investigate the effects of beacon technology applications on consumer happiness and loyalty at Global Village in Dubai, United Arab Emirates. This research takes a deductive approach. It uses quantitative data to conclude. A survey was employed as a data collection approach in this quantitative method to test hypotheses and model validity. In addition, a questionnaire was created and delivered to a sample of retailers in Dubai's Global Village. The questionnaire was aimed at store owners and managers. SPSS (Statistical Package for the Social Sciences) was used to analyze the data and obtain the results using regression, ANOVA, and correlations. Because of the nature of this type of business, we chose the Global Village in Dubai. In Dubai's Global Village, there are around 3000 shops. It brings together the cultures of 90 countries from around the world in one location. It is a close-knit community of stores with an annual visitor count of over 7 million, making proximity marketing an attractive option for businesses looking to boost sales. Because the study requires the shop to use internet of things tools in their operations and marketing, we chose the con sample type. We targeted 347 stores, with 159 of them meeting the study's criteria. Out of the total distributed questionnaires, 138 were found to be valid and were used in the study.

\section{Analyse the data}

We used ANOVA, regression, and correlations analysis in SPSS to examine the data in order to investigate the direct and indirect influence of Beacon technology applications on Customer Loyalty through Customer Satisfaction at Global Village in Dubai (Statistical Package for the Social Sciences).

Table 1

Descriptive analysis of study variables and Dimensions

\begin{tabular}{|c|c|c|c|}
\hline Variables and Dimensions & Mean & Std & Sig Rank \\
\hline Proximity Marketing & 3.88 & 0.98 & 1 - High \\
\hline Loyalty Programs & 3.68 & 0.87 & 5 - High \\
\hline In-store navigation & 3.83 & 0.92 & 2 - High \\
\hline Real-time Marketing & 3.69 & 0.81 & 4 - High \\
\hline Beacons technology applications & 3.79 & 0.87 & 3 - High \\
\hline Customer satisfaction & 3.66 & 0.85 & 6 - High \\
\hline Customer Loyalty & 3.65 & 0.96 & 7 - High \\
\hline
\end{tabular}

Table 1 shows the significance of study variables and dimensions, with averages ranging from 3.65 to 3.88 . The dimension "Proximity Marketing" has the highest arithmetic mean (3.88), and the Standard deviation is the lowest (0.98). While the dimension "Customer Loyalty" had the lowest mean (3.65), Standard deviation (0.96), it indicates that the Importance or significant level of study's variables and dimensions at Global Village in Dubai were all high, according to the perception of the study's sample.

\section{Testing of Hypotheses}

The analytical results of the link and influence of Beacon technology applications on Customer Satisfaction are shown in Table 2.

Table 2

The results of ANOVA Analysis and Regression Analysis of Beacon technology applications in Customer Satisfaction

\begin{tabular}{|c|c|c|c|c|c|c|c|c|c|}
\hline & $(\mathrm{r})$ & $\left(r^{2}\right)$ & Calculated F & DF & Sig* & $\beta$ & & Calculate " $t$ " & Sig* \\
\hline \multirow{4}{*}{$\begin{array}{l}\text { Customer } \\
\text { Satisfaction }\end{array}$} & \multirow{4}{*}{0.587} & \multirow{4}{*}{0.345} & \multirow{4}{*}{49.582} & 1 & \multirow{4}{*}{0.000} & Proximity Marketing & 0.0295 & 5.452 & 0.000 \\
\hline & & & & \multirow{2}{*}{134} & & Loyalty Programs & 0.0249 & 3.508 & 0.001 \\
\hline & & & & & & In-store navigation & 0.0441 & 3.575 & 0.001 \\
\hline & & & & 138 & & Real-time Marketing & 0.412 & 6.357 & 0.000 \\
\hline
\end{tabular}

*The impact is significant at level $(\alpha \leq 0.05)$

The " $r$ " was $(0.578)$ at level $(\alpha \leq 0.05)$. Whereas the $\mathrm{r}^{2}$ was $(0.345)$. This means the $(0.345)$ of Customer Loyalty changeability's results from the changeability in Beacon technology applications variables. As $\beta$ was (Proximity Marketing $=0.259$; Loyalty Programs $=0.249$; In-store navigation $=0.441$ and Real-time Marketing $=0.412$ ) this means the increase of one unit in Customer Loyalty concerned will increase Beacon technology applications variables by (0.345), Confirms significant 
impact F calculated was (49.582) and its significance at level $(\alpha \leq 0.05)$. So, we have adequate evidence to validate the first hypothesis, which states that Beacon technology applications (Proximity Marketing, Loyalty Programs, In-store navigation, and Real-time Marketing) have a substantial positive direct influence on customer loyalty at Global Village in Dubai at level $(\alpha \leq 0.05)$. As shown in Table (3), the analysis results of the relationship and impact of Beacon technology applications in Customer Loyalty.

Table 3

ANOVA Analysis and Regression Analysis of Beacon technology applications in Customer Loyalty

\begin{tabular}{|c|c|c|c|c|c|c|c|c|c|}
\hline & (r) & $\left(r^{2}\right)$ & Calculated F & $\mathrm{DF}$ & Sig* & $\beta$ & & Calculated " $\mathrm{t}$ " & Sig* \\
\hline \multirow{4}{*}{ Customer Loyalty } & \multirow{4}{*}{0.549} & \multirow{4}{*}{0.301} & \multirow{4}{*}{33.051} & 1 & \multirow{4}{*}{0.000} & Proximity Marketing & 0.561 & 2.685 & 0.000 \\
\hline & & & & \multirow{2}{*}{134} & & Loyalty Programs & 0.397 & 2.891 & 0.005 \\
\hline & & & & & & In-store navigation & 0.480 & 3.565 & 0.000 \\
\hline & & & & 138 & & Real-time Marketing & 0.472 & 3.017 & 0.000 \\
\hline
\end{tabular}

* the impact is significant at level $(\alpha \leq 0.05)$

The " $r$ " was $(0.549)$ at level $(\alpha \leq 0.05)$, whereas the $\mathrm{r}^{2}$ was $(0.301)$. This means the $(0.301)$ of Customer Loyalty changeability's results from the changeability in Beacon technology applications variables, as $\beta$ was (Proximity Marketing $=0.561$; Loyalty Programs $=0.397$; In-store navigation $=0.480$ and Real-time Marketing $=0.472$ ) this means the increase of one unit in Customer Loyalty concerned will increase Beacon technology applications variables by (0.301). Confirms significant impact calculated "F" was (33.051) and its significance at level $(\alpha \leq 0.05)$ So, we have adequate information to confirm the second hypothesis, which states that Beacon technology applications (Proximity Marketing, Loyalty Programs, In-store navigation, and Real-time Marketing) have a substantial positive direct influence on customer loyalty at Global Village in Dubai at level $(\alpha \leq 0.05)$.

As shows in Table 4, the analysis results of the relationship and impact of Customer Satisfaction on Customer Loyalty.

Table 4

ANOVA Analysis and Regression Analysis of Customer Satisfaction in Customer Loyalty

\begin{tabular}{|c|c|c|c|c|c|c|c|c|}
\hline & (r) & $\left(r^{2}\right)$ & Calculated F & DF & Sig* & $\beta$ & Calculated " $\mathrm{t}$ " & Sig* \\
\hline Customer Loyalty & 0.642 & 0.412 & 29.163 & $\begin{array}{l}1 \\
137 \\
138\end{array}$ & 0.000 & 0.846 & 3.174 & 0.000 \\
\hline
\end{tabular}

* the impact is significant at level $(\alpha \leq 0.05)$

Table 4 shows positive results for dimensions of Customer Loyalty. As, " $r$ " was (0.642) at level $(\alpha \leq 0.05)$, whereas in same sequence the $r^{2}$ was $(0.412)$. This means the Customer Loyalty dimensions' changeability's results from the changeability in Customer Satisfaction. As $\beta$ was (0.846) this means the increase of one unit in Customer Satisfaction concerned will increase Customer Loyalty dimensions by (0.412). Confirms significant impact F Calculated was (29.163) and its significance at level $(\alpha \leq 0.05)$. So, we have enough information to support the third hypothesis, which states that at level ( $\alpha \leq 0.05)$, customer satisfaction has a large positive direct impact on customer loyalty at Global Village in Dubai.

Table 5

Path analysis test results of the impact of Beacon technology applications on Customer Loyalty through Customer Satisfaction

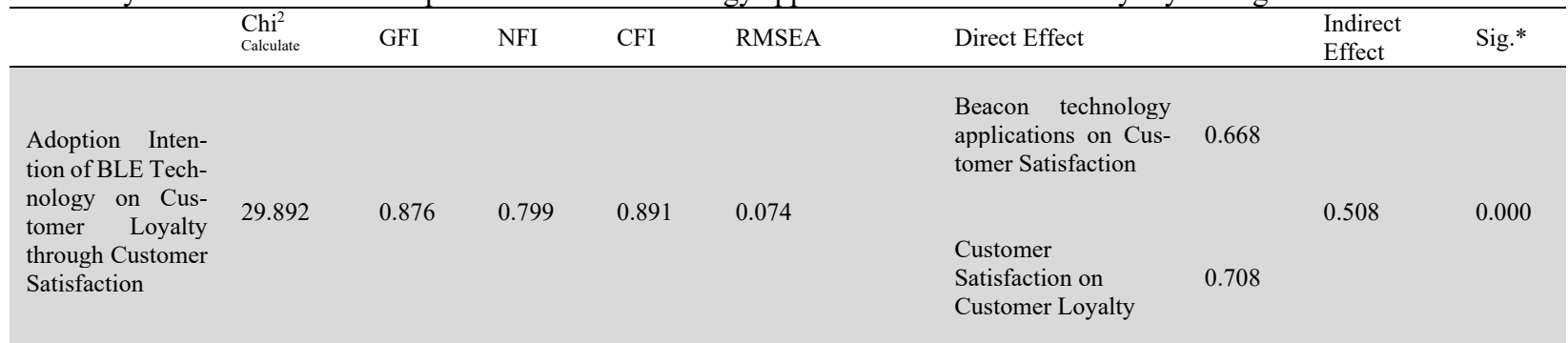

RMSEA: Root Mean Square Error of Approximation Must Proximity to Zero, GFI: Goodness of Fit Index, CFI: Comparative Fit Index, NFI: The BentlerBonett normed fit index

As shows in Table 5 the results of Path analysis of direct and indirect impact of Beacon technology applications on Customer Loyalty through Customer Satisfaction. From Table 5 we observe that there is a significant impact of Adoption Intention of BLE Technology on Customer Loyalty through Customer Satisfaction at Global Village in Dubai. The Chi ${ }^{2}$ was (29.892) at level $(\alpha \leq 0.05)$, whereas the GFI was $(0.876)$ and NFI was (0.799) and both approaching to one. On the same side the CFI was (0.891) approaching to one, while the RMSEA was (0.074) approaching to zero, like Direct Effect was (0.668) between Adoption Intention of BLE Technology and Customer Satisfaction, (0.708) between Customer Satisfaction and Customer Loyalty. The Indirect Effect was (0.508) between Adoption Intention of BLE Technology on Customer Loyalty through Customer Satisfaction at Global Village in Dubai. So, we have adequate information to support the fourth hypothesis, which states that Adoption Intention of BLE Technology have a significant positive indirect impact on Customer Loyalty through Customer 
Satisfaction at Global Village in Dubai at level $(\alpha \leq 0.05)$. The adoption of Adoption Intention of BLE Technology can be extremely beneficial to users, increasing their pleasure and loyalty. The impact of beacon technology on customer satisfaction and loyalty was investigated in this study. Customers can use beacon technology apps to reach out to all surrounding customers and support them with proximity marketing to offer them with all the information they need to guide them when they enter a store seeking for a specific brand, product, service, people, or location in a shorter amount of time. To provide the highest quality service and perceived value evaluations to all customers and consumers in order to increase positive word of mouth, which is considered part of customer loyalty.

\section{Discussion}

BLE (Beacons) Technology, like any other technology, have a wide range of applications. It has both advantages and disadvantages; BLE (Beacons) Technology elevate the consumer experience to a new level, resulting in customer happiness and, of course, customer loyalty. Beacon technology applications are pretty crucial for giving a better customer experience. Organizations may add value by employing real-time insights and giving real-time data to customers (Swamy, Harinishree, Harshitha, Venkatesh, \& Firdaus, 2018). The benefit notion is critical for determining how customers will react to a particular product or service and this is what Beacon technology applications are all about. Through their intelligent devices, beacon technology applications can guide customers to places, people, or the finest products with the best offers and bargains. Furthermore, beacon technology can operate as an advertising tool, sending advertising messages to customers about the offers of shops and businesses right away (Okamoto et al., 2017). Furthermore, beacon technology applications may lead to a rise in proximity marketing, targeting potential customers with personalized adverts based on how close the consumer/device is to a given area and enticing them to make a purchase choice. It also assists in saving customers significant time and offering an in-store consumer experience that can boost customer satisfaction (Spachos \& Plataniotis, 2020). Customer loyalty programs are all about keeping current customers engaged and satisfied while also monitoring their experience. Loyalty programs are commercial techniques aimed at keeping customers loyal to a specific brand. Marketers can better understand their target consumer's behavior, location, demographics, and behaviors via beacon technology applications (Rajamohanan, Hariharan, \& Menon, 2019). Furthermore, Beacon technology applications enable marketers to target clients with greater precision, allowing them to reduce the number of negative impressions. Marketers may use this solution to get all of their offers and incentives to their customers faster, resulting in increased purchase intent and improved customer satisfaction and loyalty (Kalbandhe \& Patil, 2017).

\section{Conclusion}

Customer happiness is a subject of numerous influencing elements, including service quality, pricing fairness, and perceived value. Beacon technology applications are created primarily to satisfy more customers of various ages for meeting their requirements and wishes in the cheapest and easiest method possible. Customer happiness can lead to good word of mouth and a higher likelihood of repeat purchases, demonstrating consumer loyalty. As a result, consumer happiness can lead to customer loyalty or have a beneficial impact on customer loyalty (Kusaladharma \& Tellambura, 2013). Beyond privacy, beacon relevance and usability are critical. Beacons have the potential to transform how brick-and-mortar merchants communicate with their customers. Shoppers may expect a more seamless, engaging, and personalized experience. Simultaneously, retailers can acquire valuable knowledge of their customers (Yanagaimoto, Hashimoto, \& Matsuo, 2018). According to Business Insider Intelligence Report, by 2018, 4.5 million beacons are expected to be operational in the United States. These figures demonstrate that this technology will become a critical component of retailing.

\subsection{Limitations}

The purpose of this study was to see how beacon technology affects consumer pleasure and loyalty. In truth, finding a research study without any restrictions is difficult; similarly, this study had a few limitations, which are described below:

- The goal of this study was to look only at the beneficial effects of beacon technology on customer satisfaction and loyalty, not the negative ones.

- The sample size for this research study was confined to Global Village visitors in the UAE, making it difficult to generalize the information gathered.

- Despite its potential, businesses face an uphill battle with perceived privacy. According to studies, customers are incredibly averse to being tracked in-store, even if it improves the customer experience.

- Additionally, beacons rely on apps installed on devices. For most businesses and brands, customers must download their app before the beacon signal may communicate with a device.

\subsection{Theoretical and Practical Implications}

Some businesses are already attempting to overcome these obstacles through strategic partnerships and investments. For instance, Twitter recently invested an impressive $\$ 18$ million in Swirl, a beacon marketing start-up. So how does Swirl benefit specifically from the social media app? The answer is straightforward; it comes down to user-friendliness. 
Twitter is a widely used application that almost everyone has installed on their phone or tablet. With over 250 million monthly active users, it's a goldmine of engagement for brands and marketers. Not to mention, Twitter works regardless of whether there is a WiFi signal.

While details are still being worked out, Swirl and Twitter may be a match made in heaven. Brands and merchants can rely on Twitter and its massive user base to provide them with beacons. Consider the following scenario. We are in our favorite store, ready to treat yourself to something nice. We have Bluetooth turned off to conserve battery life and would much instead download all of the Candy Crush sagas than your favorite store's app, which is approximately 30 MB in size on your phone. That is quite a sum! We come across an item we wish to purchase only to discover it is out of your price range. We return it and continue shopping until we come across a beacon hotspot that sends you an automatic tweet from a brand you follow. We receive the tweet and immediately feel special! It states, "All goods are now 20\% off at your neighborhood department store." A big smile and a warm feeling wash over us, and we happily return to your dream purchase and make it, feeling great that we saved money and knowing that our favorite brand takes the time to notify us about deals and has our back. Because the integration with Twitter is so simple to use, it can be an excellent source for beacon marketing. We create an account and subscribe to our own brand's feed. That is all. There is no additional downloading or registration required. It effectively eliminates beacon marketing's flaws at no cost to the user. Of course, beacon marketing is still in its infancy, and there is much room for growth. However, understanding the consumer and the evolution of mobile technology may provide critical insights into the evolution of beacon marketing as a new, interactive channel for engagement.

\subsection{Suggestions for Future Research:}

- Future research should look into the same model in different industries to see any comparable findings.

- Additional research should be conducted to determine the influence of beacon technology applications on various variables such as firm performance or the effective work environment of a company.

- In addition, more research is needed into the influence of various forms of location-based technology on consumer happiness and loyalty.

\section{References}

Abu Zayyad, H. M., Obeidat, Z. M., Alshurideh, M. T., Abuhashesh, M., Maqableh, M., \& Masa'deh, R. (2021). Corporate social responsibility and patronage intentions: The mediating effect of brand credibility. Journal of Marketing Communications, 27(5), 510 533. https://doi.org/10.1080/13527266.2020.1728565

Abuhashesh, M. Y., Alshurideh, M. T., \& Sumadi, M. (2021). The effect of culture on customers' attitudes toward Facebook advertising: the moderating role of gender. Review of International Business and Strategy.

Ahmad, A., Alshurideh, M. T., Al Kurdi, B. H., \& Salloum, S. A. (2021). Factors Impacts Organization Digital Transformation and Organization Decision Making During Covid19 Pandemic. The Effect of Coronavirus Disease (COVID-19) on Business Intelligence, 95 .

Akbar, M. M., \& Parvez, N. (2009). IMPACT OF SERVICE QUALITY, TRUST , AND CUSTOMER Mohammad Muzahid Akbar and Noorjahan Parvez. ABAC Journal, 29(1), 24-38.

Al-Khayyal, A., Alshurideh, M., Al Kurdi, B., \& Salloum, S. A. (2020). Factors Influencing Electronic Service Quality on Electronic Loyalty in Online Shopping Context: Data Analysis Approach. In Enabling AI Applications in Data Science (pp. 367-378). Springer.

Al Dmour, H., Alshurideh, M., \& Shishan, F. (2014). The influence of mobile application quality and attributes on the continuance intention of mobile shopping. Life Science Journal, 11(10), 172-181.

Al Kurdi, B, Alshurideh, M., \& Al afaishata, T. (2020). Employee retention and organizational performance: Evidence from banking industry. Management Science Letters, 10(16), 3981-3990.

Al Kurdi, Barween, Alshurideh, M., \& Salloum, S. A. (2020). Investigating a theoretical framework for e-learning technology acceptance. International Journal of Electrical and Computer Engineering (IJECE), 10(6), 6484-6496.

Al Kurdi, Barween, Alshurideh, M., Salloum, S. A., Obeidat, Z. M., \& Al-dweeri, R. M. (2020). An Empirical Investigation into Examination of Factors Influencing University Students' Behavior towards Elearning Acceptance Using SEM Approach. International Journal of Interactive Mobile Technologies (IJIM), 14(02), 19-41.

Alaali, N., Al Marzouqi, A., Albaqaeen, A., Dahabreh, F., Alshurideh, M., Mouzaek, E., ... Aburayya, A. (2021). The impact of adopting corporate governance strategic performance in the tourism sector: A case study in the Kingdom of Bahrain. Journal of Legal, Ethical and Regulatory Issues, 24(Special Issue 1), 1-18. Retrieved from https://www.scopus.com/inward/record.uri?eid=2-s2.085112793391\&partnerID $=40 \& m d 5=$ fefbffeaf1d5d7307d9b3107bdfadb47

Alameeri, K. A., Alshurideh, M. T., \& Al Kurdi, B. (2021). The Effect of Covid-19 Pandemic on Business Systems' Innovation and Entrepreneurship and How to Cope with It: A Theatrical View. The Effect of Coronavirus Disease (COVID-19) on Business Intelligence, $334,275-288$.

Alameeri, K., Alshurideh, M., A1 Kurdi, B., \& Salloum, S. A. (2021). The Effect of Work Environment Happiness on Employee Leadership. Advances in Intelligent Systems and Computing, pp. 668-680. https://doi.org/10.1007/978-3-030-58669-0_60

Alhamad, A. Q. M., Akour, I., Alshurideh, M., Al-Hamad, A. Q., Kurdi, B. Al, \& Alzoubi, H. (2021). Predicting the intention to use google glass: A comparative approach using machine learning models and PLS-SEM. International Journal of Data and Network Science, 5(3), 311-320. https://doi.org/10.5267/j.ijdns.2021.6.002

Ali, N., Ahmed, A., Anum, L., Ghazal, T. M., Abbas, S., Khan, M. A., ... Ahmad, M. (2021). Modelling supply chain information collaboration empowered with machine learning technique. Intelligent Automation and Soft Computing, 30(1), $243-257$. https://doi.org/10.32604/iasc.2021.018983

Aljumah, A., Nuseir, M. T., \& Alshurideh, M. T. (2021). The Impact of Social Media Marketing Communications on Consumer Response 
During the COVID-19: Does the Brand Equity of a University Matter. The Effect of Coronavirus Disease (COVID-19) on Business Intelligence, 334, 384-367.

Alkitbi, S. S., Alshurideh, M., Al Kurdi, B., \& Salloum, S. A. (2021). Factors Affect Customer Retention: A Systematic Review. In Advances in Intelligent Systems and Computing. https://doi.org/10.1007/978-3-030-58669-0_59

Alnazer, N. N., Alnuaimi, M. A., \& Alzoubi, H. M. (2017). Analysing the appropriate cognitive styles and its effect on strategic innovation in Jordanian universities. International Journal of Business Excellence, 13(1), 127-140.

Alnuaimi, M., Alzoubi, H. M., Ajelat, D., \& Alzoubi, A. A. (2021). Towards intelligent organisations: an empirical investigation of learning orientation's role in technical innovation. International Journal of Innovation and Learning, 29(2), 207-221.

AlShehhi, H., Alshurideh, M., Al Kurdi, B., \& Salloum, S. A. (2020). The impact of ethical leadership on employees performance: A systematic review. International Conference on Advanced Intelligent Systems and Informatics, 417-426. Springer.

Alshraideh, A., Al-Lozi, M., \& Alshurideh, M. (2017). The Impact of Training Strategy on Organizational Loyalty via the Mediating Variables of Organizational Satisfaction and Organizational Performance: An Empirical Study on Jordanian Agricultural Credit Corporation Staff. Journal of Social Sciences (COES\&RJ-JSS), 6, 383-394.

Alshurideh. (2019). Do electronic loyalty programs still drive customer choice and repeat purchase behaviour? International Journal of Electronic Customer Relationship Management, 12(1), 40-57.

Alshurideh, M., Masa'deh, R. M. d. T., \& Alkurdi, B. (2012). The effect of customer satisfaction upon customer retention in the Jordanian mobile market: An empirical investigation. European Journal of Economics, Finance and Administrative Sciences, 47(47), 69-78.

Alsuwaidi, M., Alshurideh, M., Al Kurdi, B., \& Salloum, S. A. (2020). Performance appraisal on employees' motivation: A comprehensive analysis. International Conference on Advanced Intelligent Systems and Informatics, 681-693. Springer.

Alzoubi, H. M., Ahmed, G., Al-Gasaymeh, A., \& Al Kurdi, B. (2020). Empirical study on sustainable supply chain strategies and its impact on competitive priorities: The mediating role of supply chain collaboration. Management Science Letters, 10(3), 703-708. https://doi.org/10.5267/j.msl.2019.9.008

Alzoubi, H. M., Alshurideh, M., \& Ghazal, T. M. (2021). Integrating BLE Beacon Technology with Intelligent Information Systems IIS for Operations' Performance: A Managerial Perspective. The International Conference on Artificial Intelligence and Computer Vision, 527-538.

Alzoubi, H. M., \& Aziz, R. (2021). Does Emotional Intelligence Contribute to Quality of Strategic Decisions? The Mediating Role of Open Innovation. Journal of Open Innovation: Technology, Market, and Complexity, 7(2), 130.

Alzoubi, H. M., Vij, M., Vij, A., \& Hanaysha, J. R. (2021). What leads guests to satisfaction and loyalty in UAE five-star hotels? AHP analysis to service quality dimensions. Enlightening Tourism, 11(1), 102-135. https://doi.org/10.33776/et.v11i1.5056

Alzoubi, H. M., \& Yanamandra, R. (2020). Investigating the mediating role of Information Sharing Strategy on Agile Supply Chain in Supply Chain Performance. Uncertain Supply Chain Management, 8(2), 273-284.

Alzoubi, H. (2018). The role of intelligent information system in e-supply chain management performance. International Journal of Multidisciplinary Thought, 7(2), 363-370.

Alzoubi, Haitham, \& Ahmed, G. (2019). Do TQM practices improve organisational success? A case study of electronics industry in the UAE. International Journal of Economics and Business Research, 17(4), 459-472.

Bhattacharya, D., Canul, M., \& Knight, S. (2016). Impact of the Physical Web and BLE Beacons. RIIT 2016 - Proceedings of the 5th Annual Conference on Research in Information Technology, 53. https://doi.org/10.1145/2978178.2978179

Bhosale, A., Benny, G., Jaison, R., Khot, A., \& Pati, S. (2019). Beacons. (Icnte).

Bulusu, N., Heidemann, J., \& Estrin, D. (2001). Adaptive beacon placement. Proceedings - International Conference on Distributed Computing Systems, (May), 489-498. https://doi.org/10.1109/icdsc.2001.918979

Chen, D., Shin, K. G., Jiang, Y., \& Kim, K.-H. (2017). Locating and tracking ble beacons with smartphones. Proceedings of the 13th International Conference on Emerging Networking EXperiments and Technologies, 263-275.

Dudhane, N. A., \& Pitambare, S. T. (2015). Location Based and Contextual Services Using Bluetooth Beacons: New Way to Enhance Customer Experience. Lecture Notes on Information Theory, 3(1), 31-34. https://doi.org/10.18178/lnit.3.1.31-34

Fernandes, K. (2021). Designing a Returns Logistics Process for an E-commerce Business Model. (April).

Gajanova, L. (2019). The potential of using Bluetooth-based system as a part of proximity marketing in the Slovak Republic. Marketing and Management of Innovations, 2(2), 239-252. https://doi.org/10.21272/mmi.2019.2-21

Ghazal, T. M., Hasan, M. K., Alshurideh, M. T., Alzoubi, H. M., Ahmad, M., Akbar, S. S., ... Akour, I. A. (2021). IoT for Smart Cities: Machine Learning Approaches in Smart Healthcare-A Review. Future Internet, 13(8), 218. https://doi.org/10.3390/fi13080218

Girolami, M., Mavilia, F., \& Delmastro, F. (2020). Sensing social interactions through BLE beacons and commercial mobile devices. Pervasive and Mobile Computing, 67, 1-16.

Gómez-de-Gabriel, J. M., Fernández-Madrigal, J. A., López-Arquillos, A., \& Rubio-Romero, J. C. (2019). Monitoring harness use in construction with BLE beacons. Measurement, 131, 329-340.

Hamadneh, S., \& Al Kurdi, B. (2021). The Effect of Brand Personality on Consumer Self-Identity: The Moderation Effect of Cultural Orientations Among British and Chinese Consumers. Journal of Legal, Ethical and Regulatory Issues, 24(Special Issue 1), 1-14.

Joghee, S., Al Kurdi, B., Alshurideh, M., Alzoubi, H., Vij, A., Muthusamy, M. \& HamadneH, S. (2021). Expats Impulse Buying Behaviour in UAE: A Customer Perspective. Journal of Management Information and Decision Sciences, 24(Special Issue 1), 1-24.

Joghee, S., Alzoubi, H. M., \& Dubey, A. R. (2020). Decisions effectiveness of FDI investment biases at real estate industry: Empirical evidence from Dubai smart city projects. International Journal of Scientific and Technology Research, 9(3), 3499-3503.

Johnson, E. C., Karlay, J. S., Fregidou-Malama, M., Hyder, A., \& Johnson, E. C. (2018). Impact of Service Quality on customer Satisfaction Liberia Revenue Authority.

Kalbandhe, A. A., \& Patil, S. C. (2017). Indoor Positioning System using Bluetooth Low Energy. International Conference on Computing, Analytics and Security Trends, CAST 2016, (December 2016), 451-455. https://doi.org/10.1109/CAST.2016.7915011

Konečnik Ruzzier, M., Ruzzier, M., \& Hisrich, R. (2014). Value, satisfaction and customer loyalty. Marketing for Entrepreneurs and SMEs, (November), 21-36. https://doi.org/10.4337/9781781955970.00008

Al Kurdi, B., Elrehail, H., Alzoubi, H., Alshurideh, M., \& Al-Adaila, R. (2021). The interplay among HRM practices, job satisfaction and intention to leave: An empirical investigation. Journal of Legal, Ethical and Regulatory, 24(1), 1-14.

Kurdi, B, Alshurideh, M., \& Alnaser, A. (2020). The impact of employee satisfaction on customer satisfaction: Theoretical and empirical underpinning. Management Science Letters, 10(15), 3561-3570. 
Kusaladharma, S., \& Tellambura, C. (2013). Impact of beacon misdetection on aggregate interference for hybrid underlay-interweave networks. IEEE Communications Letters, 17(11), 2052-2055.

Levesque, N., \& Boeck, H. (2017). Proximity Marketing as an Enabler of Mass Customization and Personalization in a Customer Service Experience. (December 2016), 405-420. https://doi.org/10.1007/978-3-319-29058-4_32

Levesque, N., Durif, F., Boeck, H., \& Bilolo, A. (2015). The impact of Proximity Marketing on consumer reaction and firm performance: A conceptual and integrative model. 2015 Americas Conference on Information Systems, AMCIS 2015, (August).

Madi Odeh, R. B. S., Obeidat, B. Y., Jaradat, M. O., Masa'deh, R., \& Alshurideh, M. T. (2021). The transformational leadership role in achieving organizational resilience through adaptive cultures: the case of Dubai service sector. International Journal of Productivity and Performance Management. https://doi.org/10.1108/IJPPM-02-2021-0093

Mashaqi, E., Al-Hajri, S., Alshurideh, M., \& Al Kurdi, B. (2020). The impact of E-Service quality, E-Recovery services on E-Loyalty in online shopping: theoretical foundation And qualitative proof. PalArch's Journal of Archaeology of Egypt/Egyptology, 17(10), 22912316.

Mehmood, T., Alzoubi, H. M., Alshurideh, M., Al-Gasaymeh, A., \& Ahmed, G. (2019). Schumpeterian entrepreneurship theory: evolution and relevance. Academy of Entrepreneurship Journal, 25(4), 1-10.

Moody, M. (2015). Analysis of Promising Beacon Technology for Consumers. The Elon Journal of Undergraduate Research in Communications, 6(1), 59-68.

Nemati, A. R., Khan, K., \& Iftikhar, M. (2010). Impact of innovation on customer satisfaction and brand loyalty, a study of mobile phones users in Pakistan. European Journal of Social Sciences, 16(2), 307-314.

Ng, P. C., She, J., \& Ran, R. (2020). A reliable smart interaction with physical thing attached with ble beacon. IEEE Internet of Things Journal, 7(4), 3650-3662.

Nicholas, G., \& Shapiro, A. (2021). Failed hybrids: The death and life of Bluetooth proximity marketing. Mobile Media and Communication, 9(3), 465-487. https://doi.org/10.1177/2050157920975836

Nuseir, M. T., Aljumah, A., \& Alshurideh, M. T. (2021). How the Business Intelligence in the New Startup Performance in UAE During COVID-19: The Mediating Role of Innovativeness. The Effect of Coronavirus Disease (COVID-19) on Business Intelligence, 63-79.

Obeidat, U., Obeidat, B., Alrowwad, A., Alshurideh, M., Masadeh, R., \& Abuhashesh, M. (2021). The effect of intellectual capital on competitive advantage: The mediating role of innovation. Management Science Letters, 11(4), 1331-1344.

Okamoto, T., Sasaki, Y., \& Suzuki, S. (2017). Targeted advertising using BLE beacon. 2017 IEEE 6th Global Conference on Consumer Electronics (GCCE), 1-5. IEEE.

Rajamohanan, D., Hariharan, B., \& Menon, K. A. U. (2019). Survey on Smart Health Management using BLE and BLE Beacons. 2019 9th International Symposium on Embedded Computing and System Design (ISED), 1-5. IEEE.

Ryding, D. (2010). The impact of new technologies on customer satisfaction and business to business customer relationships: Evidence from the soft drinks industry. Journal of Retailing and Consumer Services, 17(3), 224-228. https://doi.org/10.1016/j.jretconser.2010.03.008

Santouridis, I., \& Trivellas, P. (2010). Investigating the impact of service quality and customer satisfaction on customer loyalty in mobile telephony in Greece. TQM Journal, 22(3), 330-343. https://doi.org/10.1108/17542731011035550

Shirkhodaie, M., \& Rastgoo-deylami, M. (2016). Positive Word of Mouth Marketing: Explaining the Roles of Value Congruity and Brand Love. Journal of Competitiveness, 8(1), 19-37. https://doi.org/10.7441/joc.2016.01.02

Siddiqi, K. O. (2011). Interrelations between Service Quality Attributes, Customer Satisfaction and Customer Loyalty in the Retail Banking Sector in Bangladesh. International Journal of Business and Management, 6(3), 12-36. https://doi.org/10.5539/ijbm.v6n3p12

Spachos, P., \& Plataniotis, K. (2020). Ble beacons in the smart city: Applications, challenges, and research opportunities. IEEE Internet of Things Magazine, 3(1), 14-18.

Swamy, B. S., Harinishree, M. S., Harshitha, R., Venkatesh, S., \& Firdaus, R. (2018). BLE Beacon Based Museum Knowledge Sharing Platform. 3rd National Conference on Image Processing, Computing, Communication, Networking and Data Analytics, 94-98.

Turki, A. M., Barween, A. K., Ra'ed, M., \& A., S. S. (2021, January 1). The moderation effect of gender on accepting electronic payment technology: a study on United Arab Emirates consumers. Review of International Business and Strategy. https://doi.org/10.1108/RIBS08-2020-0102

Yanagaimoto, H., Hashimoto, K., \& Matsuo, T. (2018). Indoor Positioning Estimation Using BLE Beacons. 2018 International Joint Symposium on Artificial Intelligence and Natural Language Processing (ISAI-NLP), 1-6. IEEE.

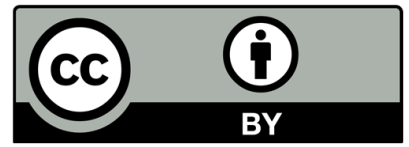

(C) 2022 by the authors; licensee Growing Science, Canada. This is an open access article distributed under the terms and conditions of the Creative Commons Attribution (CC-BY). license (http://creativecommons.org/licenses/by/4.0/). 